\title{
South Africa's New African Language Dictionaries and their Use for the African Speech Communities*
}

\author{
Juliane Klein, University of Leipzig, Leipzig, Germany \\ (julianeklein.trier@googlemail.com)
}

\begin{abstract}
During the last 15 years, the lexicographic scene in South Africa changed drastically as many new dictionaries for the African languages were compiled. The different dictionary types and publication modes discussed in this article are: general dictionaries, restricted dictionaries, printed dictionaries, electronic dictionaries, online and cell phone dictionaries. Although there are different dictionary types, they all have three major uses for the speech communities. Dictionaries are useful tools for language documentation and standardization, as they try to cover and document the general vocabulary (general dictionaries) or the specialized vocabulary (technical dictionaries). They empower the language users because they help to improve communication by providing users with the necessary vocabulary they need. In addition, dictionaries have a high symbolic value for a language. Having dictionaries, and especially technical, online or cell phone dictionaries, is the visible proof that a language is standardized and modern, and can be used in all domains of life.
\end{abstract}

Keywords: LEXICOGRAPHY, GENERAL DICTIONARIES, RESTRICTED DICTIONARIES, ONLINE DICTIONARIES, CELL PHONE DICTIONARIES, LANGUAGE DOCUMENTATION, LANGUAGE STANDARDIZATION, EMPOWERMENT, COMMUNICATION, PSYCHOLOGICAL FACTOR, SOCIOLINGUISTICS, LANGUAGE PLANNING

Opsomming: Suid-Afrika se nuwe Afrikataalwoordeboeke en hul gebruik vir die Afrikataalgemeenskappe. Gedurende die afgelope 15 jaar het die leksikografiese toneel in Suid-Afrika ingrypend verander deurdat baie nuwe woordeboeke vir die Afrikatale saamgestel is. Die verskillende woordeboeksoorte en publikasievorme wat in hierdie artikel bespreek word, is: algemene woordeboeke, beperkte woordeboeke, gedrukte woordeboeke, aanlyn- en selfoonwoordeboeke. Alhoewel daar verskillende woordeboeksoorte is, het hulle almal drie hoofgebruike vir die taalgemeenskappe. Woordeboeke is nuttige werktuie vir taaldokumentasie en -standaardisering deurdat hulle probeer om die algemene woordeskat (algemene woordeboeke) en die gespesialiseerde woordeskat (tegniese woordeboeke) te dek en te dokumenteer. Hulle bemagtig die taalgebruikers omdat hulle kommunikasie verbeter deur die gebruikers van die nodige woor-

* This article is a revised version of a paper presented at the Thirteenth International Conference of the African Association for Lexicography, organized by the Bureau of the Woordeboek van die Afrikaanse Taal, Stellenbosch, Republic of South Africa, 30 June-3 July 2008. 
deskat wat hulle benodig, te voorsien. Daarbenewens het woordeboeke ' $n$ hoë simboliese waarde vir ' $n$ taal. Om woordeboeke te besit, en veral tegniese, aanlyn- en selfoonwoordeboeke, is 'n sigbare bewys dat ' $n$ taal gestandaardiseer en modern is, en op alle terreine van die lewe gebruik word.

Sleutelwoorde: LEKSIKOGRAFIE, ALGEMENE WOORDEBOEKE, BEPERKTE WOORDEBOEKE, AANLYNWOORDEBOEKE, SELFOONWOORDEBOEKE, TAALDOKUMENTASIE, TAALSTANDAARDISERING, BEMAGTIGING, KOMMUNIKASIE, SIELKUNDIGE FAKTOR, SOSIOLINGUISTIEK, TAALBEPLANNING

\section{Introduction and sociolinguistic background}

The lexicographic scene in South Africa changed markedly after the 1996 Constitution and the establishment of the eleven National Lexicographic Units. The last decade saw the compilation of many African language dictionaries. This article discusses these new dictionaries and their use for the African language speech communities. In addition, the need to establish a dictionary culture will be discussed, as a functional dictionary culture can help to empower people.

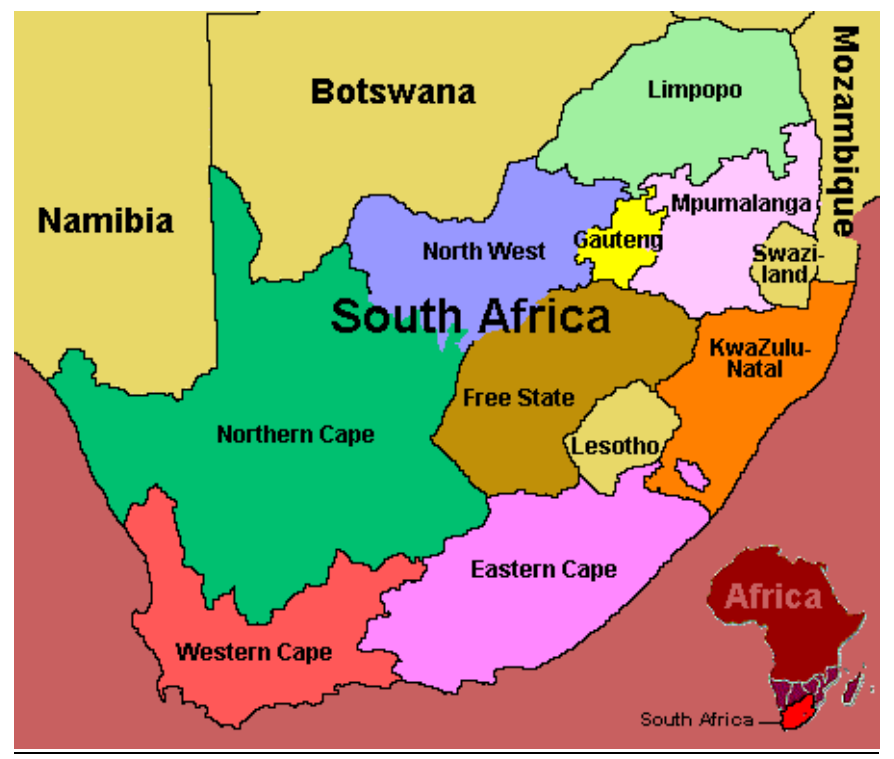

This map shows South Africa with its nine provinces (www.afrilux.co.za/ quickies/South_Africa.htm).

South Africa is a sociolinguistically complex country, which is "characterized by: a multiplicity of languages and cultures; an overlapping demographical and geographical distribution of languages; the politicisation of its languages and cultures due to the colonial past and the policy of apartheid" (Webb 1996: 
143). It is not possible to give the exact number of languages spoken in South Africa. Webb and Kembo-Sure (2000: 50) indicate that there are between 25 and 80 languages. In contrast to this high number, Ethnologue lists 31 languages of which "25 are living languages, 3 are second languages without mother-tongue speakers, and 3 are extinct". It has eleven official languages, of which nine are African languages, i.e. Ndebele, Sesotho, Sesotho sa Leboa, Setswana, SiSwati, Tsonga, Venda, Zulu and Xhosa, and two are Germanic languages, i.e. Afrikaans and English.

Table 1: Home languages in the nine provinces (Census 2001)

\begin{tabular}{|l|r|r|r|r|r|r|r|r|r|r|}
\hline $\begin{array}{c}\text { Home } \\
\text { language }\end{array}$ & $\begin{array}{c}\text { Eastern } \\
\text { Cape }\end{array}$ & $\begin{array}{c}\text { Free } \\
\text { State }\end{array}$ & Gauteng & $\begin{array}{c}\text { KwaZulu } \\
\text { Natal }\end{array}$ & Limpopo & Mpumalanga & $\begin{array}{c}\text { Northern } \\
\text { Cape }\end{array}$ & $\begin{array}{c}\text { North } \\
\text { West }\end{array}$ & $\begin{array}{c}\text { Western } \\
\text { Cape }\end{array}$ & $\begin{array}{c}\text { South } \\
\text { Africa }\end{array}$ \\
\hline Afrikaans & 9.3 & 11.9 & 14.4 & 1.5 & 2.3 & 6.2 & 68.0 & 7.5 & 55.3 & 13.3 \\
\hline English & 3.6 & 1.2 & 12.5 & 13.6 & 0.5 & 1.7 & 2.5 & 1.2 & 19.3 & 8.2 \\
\hline IsiNdebele & 0.1 & 0.4 & 1.9 & 0.2 & 1.5 & 12.1 & 0.1 & 1.3 & 0.0 & 1.6 \\
\hline IsiXhosa & 83.4 & 9.1 & 7.6 & 2.3 & 0.3 & 1.5 & 6.2 & 5.8 & 23.7 & 17.6 \\
\hline IsiZulu & 0.8 & 5.1 & 21.5 & 80.9 & 0.7 & 26.4 & 0.3 & 2.5 & 0.2 & 23.8 \\
\hline Sepedi & 0.0 & 0.3 & 10.7 & 0.1 & 52.1 & 10.8 & 0.1 & 4.2 & 0.0 & 9.4 \\
\hline Sesotho & 2.4 & 64.4 & 13.1 & 0.7 & 1.3 & 3.7 & 1.1 & 5.7 & 0.7 & 7.9 \\
\hline Setswana & 0.0 & 6.8 & 8.4 & 0.1 & 1.6 & 2.7 & 20.8 & 65.4 & 0.1 & 8.2 \\
\hline SiSwati & 0.1 & 0.3 & 1.4 & 0.1 & 1.1 & 30.8 & 0.1 & 0.6 & 0.0 & 2.7 \\
\hline Tshivenda & 0.0 & 0.1 & 1.7 & 0.0 & 15.9 & 0.2 & 0.0 & 0.5 & 0.0 & 2.3 \\
\hline Xitsonga & 0.0 & 0.3 & 5.7 & 0.0 & 22.4 & 3.8 & 0.0 & 4.7 & 0.0 & 4.4 \\
\hline Other & 0.2 & 0.2 & 1.0 & 0.4 & 0.3 & 0.3 & 0.7 & 0.6 & 0.4 & 0.5 \\
\hline Total & 100.0 & 100.0 & 100.0 & 100.0 & 100.0 & 100.0 & 100.0 & 100.0 & 100.0 & 100.0 \\
\hline
\end{tabular}

Table 1 shows that most people speak an African language as their home language. Although most provinces have at least one dominant home language, the language distribution does not follow provincial borders. This heterogeneous occurrence explains the distribution of the official provincial languages and is a reason why all provinces have at least three official languages and have chosen at least one African language.

Table 2: Provincial languages (Geyser online resource)

\begin{tabular}{|l|l|}
\hline Province & Provincial languages \\
\hline Eastern Cape & Xhosa, Afrikaans, English, Sign language \\
\hline Free State & English, Afrikaans, Sesotho, Xhosa \\
\hline Gauteng & Afrikaans, English, Sepedi, Zulu \\
\hline KwaZulu-Natal & Zulu, Afrikaans, English \\
\hline Limpopo & Sepedi, Afrikaans, Venda, Xitsonga, Ndebele, English \\
\hline Mpumalanga & Ndebele, SiSwati, Afrikaans, English \\
\hline Northern Cape & Setswana, Afrikaans, Xhosa, English \\
\hline North West province & Setswana, Afrikaans, English, Sign language \\
\hline Western Cape & Afrikaans, English, Xhosa \\
\hline
\end{tabular}

South Africa does not only have eleven official languages, but it also has multilingualism and the development of the African languages enshrined in the constitution. This is an important aspect, as most multilingual African countries chose only the former colonial language as official language. In most countries, 
the African languages are not recognized as official languages; they either have no status or are called "national languages" without having the status and legal backing official languages have. In contrast to this, South Africa is one of the few countries providing a legal basis for the development of the indigenous languages spoken by the majority of people in South Africa.

\section{Lexicographic scene in South Africa}

The National Lexicographic Units Bill from 1996 paved the way for most of the new dictionaries in South Africa. According to the Bill, Lexicographic Units for each official language had to be established. The existing Units were not dissolved but reorganized so that they met the requirements stated in the Bill. Having such a legal backing was probably the main reason why the lexicographic scene in South Africa developed and expanded quite fast during the last decade. At present, general dictionaries are available for all official languages. These include printed dictionaries, online and cell phone dictionaries.

Because of the need felt for them, technical dictionaries and word lists are being compiled by many individual researchers and by the National Language Service. Although some technical dictionaries already exist, they are not yet widely distributed among the speech communities.

\section{Interdependent dictionary types and publication modes and their use for the people}

Although different dictionary types and publication modes can be distinguished, the boundaries between these groups are blurred as most dictionaries belong to more than one group.

\subsection{General dictionaries}

General dictionaries aim to cover the general vocabulary of a language. They can be either monolingual, bilingual or, in the case of South Africa, multilingual. The major difference between monolingual and bilingual or multilingual dictionaries is that in monolingual dictionaries, the headwords are defined in the same language as the dictionary entries, whereas bi- or multilingual dictionaries provide translations of terms or define terms in a target language if a direct translation is not possible. Bi- or multilingual dictionaries can be monodirectional, i.e. from source into target language only, or bidirectional, i.e. from source language into target language as well as from target language into source language.

General dictionaries cover the biggest user group, as they are meant for mother-tongue speakers and language learners as well. This implies that a single dictionary is used by a broad range of users, e.g. of different age groups and for a variety of tasks. An important sub-group of general dictionaries are 
school and learner's dictionaries, as they are often the first dictionaries students come in contact with. A dictionary from this category is frequently seen as the dictionary by its users. In countries where people live in a pre-dictionary culture, general dictionaries are often the only dictionaries used because they are often the only dictionaries known. In addition, specialized dictionaries mostly do not exist in a pre-dictionary culture or are not known to the speech communities. In South Africa, the general dictionary is the best-covered dictionary type, as all official languages have at least one general dictionary. Although all of these dictionaries fall into the same category, they are, depending on the compiler(s), quite different with regard to their coverage of the language. Some are very small and basic with only a few thousand entries, often just providing the lemmata and their translations, sometimes even without any part of speech information. In contrast to such word lists, other dictionaries cover more of the general vocabulary and provide much more information, for example, parts of speech, pronunciation, frequency, and usage examples.

General dictionaries are often made available as paperback or hardback editions. Other publishing modes are online dictionaries, electronic dictionaries or cell phone dictionaries.

\subsection{Restricted dictionaries}

Gouws and Prinsloo (2005: 47) define restricted dictionaries as dictionaries that "focus on one field, e.g. a specific semantic field or a specific subject domain ... or one type of lexical item ... or they limit their treatment to one data category". Some dictionaries belonging to this category are: technical dictionaries, idiom dictionaries, dictionaries of abbreviations, pronunciation dictionaries, etymological dictionaries or dictionaries of synonyms. The most important type in the South African context is technical dictionaries. English and Afrikaans are well covered, having a broad range of restricted dictionaries. The African languages, needing many more restricted and especially technical dictionaries, are still at the beginning. Nevertheless, some small online technical dictionaries exist and can be consulted by everyone who has access to the internet. Examples include a terminology list of linguistic terms in Sesotho sa Leboa and English (http:// africanlanguages.com/sdp/linguistics/), and a birds and trees list in English and Sesotho sa Leboa (http://africanlanguages.com/sdp/ff/index.php?l=en). There is also a webpage containing some basic medical terms and phrases in English and Zulu (http://www.wolfescape.com/WebPages/ZuluDict.htm). In addition, the National Language Service has published some technical dictionaries, for example: the Multilingual Natural Sciences $\mathcal{E}$ Technology Dictionary for Grade 4 to 6 (English-Afrikaans-Zulu-Xhosa-SiSwati-Ndebele; English-Afrikaans-Setswana-Sepedi-Sesotho; English-Afrikaans-Tshivenda-Xitsonga) and the Multilingual Mathematics Dictionary Grade R-6 (English into all official languages), both available in printed form or accessible online (http://www.dac. gov.za/chief_directorates/NLS/list.htm). 


\subsection{Different publication modes}

\subsubsection{Traditional paper dictionaries}

The most commonly known publication mode for dictionaries is still paper, as borne out by the fact that a dictionary is often defined as a book containing words and their translations into another language or as a book explaining the meaning of words.

An advantage of this traditional publishing mode is that the user just needs the book without requiring additional technologies, such as electricity and a computer, to be able to use it. Another advantage is that the user, by seeing the whole book, gets an idea of the size of the stock of words of the language. Nevertheless, this can be a disadvantage as well, if the dictionary contains only the basic vocabulary of a language, as this could imply that the language lacks enough words to be a "good" language. Another disadvantage is that the space in every printed dictionary is restricted so that not all words of a language can be included, and the number of examples has to be limited. Large, multivolume dictionaries which are usually expensive can also be quite intimidating for an inexperienced user because they contain too many words, making it difficult for the user to find the correct entry, especially if there is more than one volume.

\subsubsection{Electronic dictionaries}

Usually electronic dictionaries are the electronic versions of some already existing printed dictionary. They are static versions which can either be downloaded to a computer or come on a CD or as pocket organizers, palm pilots and personal digital assistants. Electronic dictionaries are as restricted as their paper versions, because they are static, needing an electronic medium to be used. Nevertheless, they are useful for users of computers for, as the dictionary is available on the computer, no other medium (book) is needed. In addition, they can be easier to use for inexperienced users who only have to type in the search word without having to browse through a book to find a word.

\subsubsection{Online dictionaries}

Online dictionaries, which can be general or restricted dictionaries, are usually dynamic dictionaries available on the internet and accessed online instead of being downloaded to the user's computer. One of the greatest advantages of online dictionaries is that they virtually have no space restrictions, so that they can contain more entries and more examples than a printed dictionary. Sound files for each entry can be added, which means that the user can listen to the correct pronunciation of a word, a very useful feature for language learners. Having no space restrictions entails that they can be compiled in a more cost- 
effective way, making the final product cheaper for the user, an important factor in economically disadvantaged societies. Another advantage is that they are dynamic, which makes it possible to easily add changes in the language or additional words and examples as well as user-feedback. Nevertheless, the great disadvantage of an online dictionary is that users either need a computer with an internet connection or a cell phone with an internet connection.

\subsubsection{Cell phone dictionaries}

Cell phone dictionaries, which is one of the newest publication modes used in South Africa, are a subcategory of electronic dictionaries. The two most common types are either downloadable dictionaries which stay on the user's cell phone or text-message based dictionaries where the user texts a query and receives a text message back containing the translation. This means that the first type is a static electronic dictionary that is downloaded to the cell phone (instead of the computer) and that can be used as long as the cell phone is operative. Pharos is compiling a set of four cell phone dictionaries, developed from Pharos's Afrikaans-English-Xhosa-Zulu Dictionary. This publisher also hopes to launch the cell phone version of Pharos's Afrikaans-English-Northern Sotho-Tswana Dictionary soon (W. Smith-Muller 2009, personal communication). The advantage here is that, because the dictionary stays on the cell phone, it is always available. A disadvantage is that such dictionaries are even more restricted in space than printed dictionaries because of the small cell phone memory card. Nevertheless, such a publication mode can be used by language planners to distribute dictionaries easily, as they could, like ring tones or games that come with the cell phone, be downloaded before the cell phones are sold. The second type is a translation service rather than a dictionary, as the user cannot access the whole dictionary but only single words.

\section{Different dictionaries and their use for the speech communities}

There are three main possibilities for the speech community: (a) Dictionaries as tools for language documentation and standardization; (b) Empowerment through communication; and (c) Psychological value of the dictionary as a status symbol for the language and its users.

\subsubsection{Documentation and standardization: general dictionaries}

A standard language is defined by Haugen (1966) as a language having minimal variation and stability in form and maximal variation in function. This means that a key feature of standardization is the creation of a uniform written variety that replaces a variety of forms with one invariable form (Milroy 1999). Such a variety can be achieved through the process of codification, i.e. through "giving explicit definition to the norm, principally through the production of 
authoritative grammars, dictionaries, spellers and the like" (Ferguson 2006: 21). Although dictionary compilers often claim that their dictionaries are descriptive and not prescriptive, dictionaries are mainly perceived as prescriptive by their users. They usually see the dictionary as an authority when it comes to spelling, i.e. the form given in the dictionary is considered to be the correct form. This is one reason why dictionaries document the standard form of a language. South African examples of dictionaries documenting the official languages are for example the Pukuntšuthaloši ya Sesotho sa Leboa (comprehensive monolingual Sesotho sa Leboa dictionary), The Greater Dictionary of IsiXhosa and the Woordeboek van die Afrikaanse Taal (WAT).

\subsubsection{Documentation and standardization: restricted dictionaries}

Not only general dictionaries but also restricted dictionaries are important tools to document and to standardize a language. Restricted dictionaries are the visible outcome of the process of lexical modernization. According to Cooper (1989: 149), "modernization ... refers to the process whereby a language becomes an appropriate medium of communication for modern topics and forms of discourse." It is mainly effected at the lexical level by enlarging the vocabulary of a language. Typical ways of enlarging the vocabulary are, for example, coining new terms, and introducing loan-words or translations into the language.

Another area of standardization is unification. Here technical dictionaries play a vital role because they provide a standardized term for a concept, i.e. there are not several different terms for one concept but only one term considered to be the standard one. Having a standard form makes communication much easier as the same term is used for the same concept. In addition, technical dictionaries pave the way for other projects, for example, HLT applications such as spell checkers, telephone interpreting systems, information systems, reservation systems or multilingual ATMs. This makes them important tools for modernizing a language.

\subsubsection{Documentation and standardization: online dictionaries}

As mentioned earlier, the advantage of online dictionaries is that they have virtually no space restrictions, which allows a thorough documentation of a language. This includes all forms of a word, not just the lemmatized stem. Online dictionaries are ideal tools for standardizing a language because new forms and words can easily be added to the dictionary — an important feature to keep it up-to-date as documentation tool during the process of standardization whenever new terms are created. A change in language use can be documented and included if the online dictionary has a user-feedback form where users can inform the compilers how they use a word or can enquire why certain words are omitted. 


\subsubsection{Empowerment through communication: general dictionaries}

General dictionaries are important tools of empowerment because they make it possible for users to speak about a broad range of topics. Bi- and multilingual dictionaries which include at least one African language, enable communication between users of different first languages, providing them with the necessary words to make themselves understandable.

School and learners' dictionaries are important subcategories of general dictionaries. They help pupils to understand the teacher and teaching materials if the medium of instruction is not their first language. An example for this would be the Oxford Bilingual School Dictionary: Northern Sotho and English. Another advantage is that they familiarize pupils with dictionaries, i.e. they learn how to use dictionaries and can profit from this knowledge when using other kinds of dictionaries. "Beginners" dictionaries introducing students to the world of dictionaries include, for example, the South African Oxford Multilingual Primary Dictionaries series (Sotho and Nguni languages), Oxford's First Bilingual Dictionary series (an African language and English) or the Pharos Multilingual Illustrated Dictionary. Although these dictionaries contain only a basic vocabulary, they are pupil-oriented, acquainting learners with the concept of dictionaries and extenuating their fear of contact with dictionaries.

General dictionaries help users to improve communication in the areas of text production, text reception, spelling, pronunciation (if this is included in the dictionary) and the usage of words (corpus-based dictionaries with usage examples).

\subsubsection{Empowerment through communication: online dictionaries}

Instead of the traditional lemmatized forms a user finds in paper dictionaries all forms of a word can be included as headwords in an online dictionary. Including all forms instead of just the stem is important for agglutinative languages, such as, for example, the Nguni languages, because this allows the inexperienced user to find a word in a dictionary. A language learner who probably does not know the stem of an unknown word found in a text can simply enter the actual word form from the text and will be lead to the correct entry and be provided with a translation.

Online dictionaries give quick and easy help, especially during text production and reception. They might become useful tools for the younger generation, as there is a growing use of the internet. As most online dictionaries are free of charge, they can be used by tertiary education students who usually have access to computers at their institutions.

\subsubsection{Empowerment through communication: restricted dictionaries}

Restricted dictionaries and especially technical dictionaries allow users to communicate on a broad range of subjects, such as, for example, medicine, law, 
languages and economy. They are useful tools for everybody who wants to reach people through languages. Journalists or radio and TV presenters of programmes broadcast in an African language need a standardized vocabulary if they want to avoid continuous code-switching, sounding incompetent for not knowing the correct words in their own language. The government and governmental organizations need specialized dictionaries in order to distribute important information in all official languages. Technical dictionaries are a prerequisite to give users access to new concepts, especially in science. If they do not possess the vocabulary, they cannot speak or write about technical topics.

\subsubsection{Empowerment through communication: cell phone dictionaries}

Because they are available virtually everywhere, cell phone dictionaries help users to communicate by providing a quick solution, i.e. a translation, for personal communications as well as when reading or writing a text. During a faceto-face communication, they might enable understanding when participants speak different languages. An important example here is the doctor-patient communications, where a misunderstanding can have tragic consequences. Cell phone dictionaries can provide instant help in such cases because they can at least provide a basic vocabulary which can help the doctor to understand the patient and the patient to comprehend what the doctor says, for example what dosage of medication to take.

\section{Symbolic value of dictionaries}

Dictionaries are valuable means to implement measures not only for corpus planning but also for status planning. They can convey a high symbolic value if they are introduced in such a way that the target users will accept and value them. In short, a dictionary can be a status symbol for a language. A dictionary is the visible proof that a language is developed and has a standard form, i.e. the language has progressed from a dialect to a "proper" language. Dictionaries can conduce first language speakers of less prestigious languages to take pride in their languages by showing them that they can be used in many domains of life. Although there are, from a linguistic point of view, no worthless languages or better languages, people perceive different languages differently. In South Africa, languages have often been used as means to suppress people, especially during the apartheid years. This led to a negative image of the African languages, especially among their mother-tongue speakers. English was seen as the language of the struggle and liberation, while the African languages were used to separate the people and to exclude them from important jobs. The implementation of the language stipulations in the new constitution and the language bill are necessary to change such negative connotations into positive ones. Dictionaries are useful tools to do so, as they are not only a visible proof of corpus planning measures but can also be used in status planning by contributing to enhance the status of a language. 


\subsection{General dictionaries as status symbols}

A comprehensive dictionary is the visible proof that the language has actually reached a similar high level as for example Afrikaans or English. It shows that the language is more than a "worthless" dialect which has no written standardized form and which lacks the vocabulary for its use in more formal domains of life. Having a multi-volume dictionary for a language shows the speakers that their language actually has an extensive vocabulary. Many of the African languages are still underrated by their mother-tongue speakers and still induce negative connotations. They are often considered worthless, because their speakers believe that they cannot be used in the workplace with their supervisors, in academic situations or when consulting doctors or lawyers. Therefore, improving the status of these languages is very important. Demonstrating that the language is developed is a difficult and protracted task but making the language visible is a first step towards enhancing its status. Compiling attractive dictionaries, i.e. dictionaries having an interesting cover and printed on good quality paper is another step towards user acceptance. Even if the first use of such an attractive-looking dictionary is just to impress visitors and show them that the possessor is proud of his culture and language, having acceptable dictionaries is important as only such products can serve as status symbols.

\subsection{Restricted dictionaries as status symbol}

For smaller languages and languages which are still not used regularly in all domains of life, it is important to have restricted and especially technical dictionaries. They show that the language actually has the vocabulary to discourse on a broad range of topics. The dictionary is a visible proof that there are words, that they have a standardized form, and that they can be used. Being able to use such standardized forms makes users to appear more educated because they can speak and write properly about a particular subject which enhances their self-esteem.

\subsection{Online and cell phone dictionaries as status symbols}

Modern publications such as online and cell phone dictionaries carry a highly emotional value as they symbolize a link between a traditional language that is still not used in all domains of life and modern technologies, as for example the internet and cell phones. In other words, they show that the language has enough status and is well enough developed to be used on the internet and on cell phones. Having a dictionary on their cell phones has another psychological advantage, because it gives the users the reassurance that they are able to communicate with the help of the dictionary which furnishes them with the 
necessary words whenever and wherever they need them.

Online dictionaries are accessible from everywhere in the world. Having online dictionaries makes a language visible and effects access to the World Wide Web. Examples of successful online dictionaries are the isiZulu.net ZuluEnglish Dictionary (http://www.isizulu.net/) and the Sesotho sa Leboa (Northern Sotho)-English Dictionary (http://www.africanlanguages.com/sdp/index.php?1 $=e n)$. Such dictionaries may also be used by people from abroad who will recognize that the language is used on the internet. Although this will mainly be an unconscious realization, it helps to change the status of a language. The language is there, it has an online dictionary, so it has progressed from a vernacular language to a modern language.

\section{Conclusion}

The lexicographic landscape in South Africa has changed during the last decade. By now all official languages have general dictionaries and some technical dictionaries have also been compiled. New publication modes have emerged; there are online and cell phone dictionaries available for the African languages. This has been made possible because the languages are supported by the constitution, and because some language planning policies have been successfully implemented. These new African language dictionaries are very important for South Africa. They can empower their speakers and can elevate the status of the languages. But to do so, they must be freely available to the speech community. As many people in South Africa still live in a pre-dictionary culture, they must be user-friendly and have a clear user-guide in order to be useful for the inexperienced user.

\section{Acknowledgements}

I am grateful to Ms A. Barfs for a very helpful and constructive critique of an earlier version of this article. However, she obviously carries no responsibility for any part of it.

\section{References}

Cooper, R. 1989. Language Planning and Social Change. Cambridge: Cambridge University Press. Ferguson, G. 2006. Language Planning and Education. Edinburgh: Edinburgh University Press.

Geyser, R. 2005. Language Distribution and the Situation in the Other Provinces [online]. http://www. fs.gov.za/.../3presentation\%20roelof\%20geyser.pp [21 February 2009].

Gordon, R.J., Jr. (Ed.). 2005. Ethnologue: Languages of the World. Fifteenth Edition. Dallas: SIL International. http://www.ethnologue.com/show_country.asp?name=ZA [23 March 2009].

Gouws, R. and D. Prinsloo. 2005. Principles and Practice of South African Lexicography. Stellenbosch: SUN PReSS 
Haugen, E. 1966. Linguistics and Language Planning. Bright, W. (Ed.). 1966. Sociolinguistics: Proceedings of the UCLA Sociolinguistics Conference, 1964: 50-70. The Hague: Mouton.

http://www.afrilux.co.za/quickies/South_Africa.htm [23 March 2009].

Joffe, D. 2003. Linguistics Terminology Sesotho sa Leboa-English [online]. http://africanlanguages. com/sdp/linguistics/ [23 March 2009].

Milroy, J. 1999. The Consequences of Standardisation in Descriptive Linguistics. Bex, T and R. Watts (Eds.). 1999. Standard English: The Widening Debate: 16-39. London: Routledge.

National Language Service. 2003. Multilingual Mathematics Dictionary Grade R-6 [online]. http:// www.deac.gov.za/chief_directorates/NLS/list.htm [23 March 2009].

National Language Service. 2005. Multilingual Natural Sciences $\mathcal{E}$ Technology Dictionary for Grade 4 to 6 [online]. http://www.deac.gov.za/chief_directorates/NLS/list.htm [23 March 2009].

TshwaneLex. 2008. Birds and Trees List: English-Sesotho sa Leboa [online]. http://africanlanguages. com/sdp/ff/index.php?l=en [23 March 2009].

Webb, V.N. 1996. Language Planning and Politics in South Africa. International Journal of the Sociology of Language 118: 139-162.

Webb, V.N. and E. Kembo-Sure. 2000. The Languages of Africa. Webb, V.N. and E. Kembo-Sure (Eds.) 2000. African Voices. An Introduction to the Languages and Linguistics of Africa: 26-54. Oxford: Oxford University Press.

Wolfe, J. 1993. Important Zulu Medical Words - Their Pronunciation and Translation [online]. http:// www.wolfescape.com/WebPages/ZuluDict.htm [23 March 2009]. 